\title{
Implementasi Random Forest Untuk Klasifikasi Motif Songket Palembang Berdasarkan SIFT
}

\author{
Siska Devella*1 ${ }^{1}$, Yohannes ${ }^{2}$, Firda Novia Rahmawati ${ }^{3}$ \\ ${ }^{1,2,3}$ STMIK Global Informatika MDP; Jalan Rajawali No. 14, (0711) 376400 \\ ${ }^{1,2,3}$ Program Studi Teknik Informatika, STMIK Global Informatika MDP, Palembang \\ e-mail: *11 siskadevella@mdp.ac.id, ${ }^{2}$ yohannesmasterous@mdp.ac.id, \\ 33irdaprase94@mhs.mdp.ac.id
}

\begin{abstract}
Abstrak
Indonesia memiliki berbagai warisan budaya tak benda salah satunya adalah kain songket. Kain songket memiliki banyak ragam sesuai ciri khas dari setiap daerah, khususnya songket Palembang. Kain songket Palembang memiliki keistimewaan dibandingkan songket dari daerah lain. Selain memiliki nilai sejarah, kain songket Palembang memiliki motif, mutu dan tingkat kerumitan yang tinggi dalam proses pembuatannya. Pada penelitian ini digunakan metode Random Forest untuk klasifikasi citra motif kain songket Palembang dengan mengunakan ekstraksi fitur Scale-Invariant Feature Transform (SIFT). Proses pembentukan fitur dengan metode SIFT melalui tahap scale space extrema detection, keypoint localization, orientation assignment, dan keypoint descriptor. Fitur yang dihasilkan digunakan untuk klasifikasi Random Forest. Citra motif songket yang digunakan pada penelitian ini sebanyak 115 citra dari setiap jenis motif, yaitu Bunga Cina, Cantik Manis, dan Pulir. Pemilihan citra diambil dari 5 warna setiap motif songket Palembang. Data latih dan data uji yang digunakan masing-masing sebanyak 100 dan 15 untuk setiap motif Songket Palembang. Hasil pengujian menunjukkan bahwa metode SIFT dan Random Forest untuk klasifikasi citra motif kain Songket Palembang dapat memberikan akurasi yang cukup baik, dimana metode SIFT dan Random Forest mampu menghasilkan rata-rata overall accuracy 92,98\%, per class accuracy 94,07\%, presision 92,98\%, dan recall $89,74 \%$.
\end{abstract}

Kata kunci-Songket Palembang, Scale-Invariant Feature Transform, Random Forest

\begin{abstract}
Indonesia has a variety of intangible cultural heritage, one of which is songket. Songket has a lot of variety according to the characteristics of each region, especially Songket Palembang. Songket Palembang has more features compared to songket from other regions. Besides having historical value, Songket Palembang has a high motive, quality, and complexity in the manufacturing process. In this study, the Random Forest method was used to classify the Songket Palembang motif image by using Scale-Invariant Feature Transform (SIFT) feature extraction. The process of feature formation using the SIFT method is through the stages of extrema detection scale space, keypoint localization, orientation assignment, and keypoint descriptor. The resulting feature is used for the Random Forest classification. Songket motif images used in this study were 115 images of each type of motif, namely Chinese Flowers, Beautiful Flowers, and Pulir. Image selection is taken from 5 colors of each Songket Palembang motif. Training data and test data used were 100 and 15 for each Songket Palembang motif, respectively. The test results show that the SIFT and Random Forest methods for the classification of Songket Palembang motifs can provide a pretty good accuracy, where the SIFT and Random Forest methods can produce an overall accuracy of $92.98 \%$, per class accuracy of $94.07 \%$, precision $92.98 \%$, and recall $89.74 \%$.
\end{abstract}

Keywords — Songket Palembang, Scale-Invariant Feature Transform, Random Forest 


\section{PENDAHULUAN}

Kain songket sebagai salah satu jati diri suku bangsa masyarakat Melayu dalam bentuk artefak. Di Indonesia, etnis Melayu mulai tersebar dari Sumatera (Sumatera Selatan, Sumatera Barat, Riau, Sumatera Timur, dan Aceh), Kalimantan, Sulawesi, Bali hingga Lombok. Teknik Pembuatan kain tenun dengan menambahkan hiasan benang emas atau perak pada jalinan benang pakan atau benang lungsi dengan cara menyungkit benang-benang disebut songket. Kain songket tidak hanya memiliki daya saing di pasar songket nusantara lokal bahkan hingga mancanegara. Kain songket Palembang memiliki keistimewaan jika dibandingkan songket yang berasal dari daerah lain. Songket asli Palembang memiliki mutu dan tingkat kerumitan yang tinggi dalam proses pembuatannya dan juga memiliki nilai sejarah. Pada generasi milenial sekarang ini sangat jarang sekali ditemukan anak - anak muda yang dapat mengenali motif songket Palembang. Sehingga sebagai penerus generasi hendaknya mencari cara untuk untuk tetap melestarikan salah satu warisan tak benda yaitu songket yang dimiliki bangsa Indonesia, dan telah terdaftar sebagai warisan budaya tak benda Indonesia untuk UNESCO (UNESCO, 2017).

Banyak cara yang digunakan untuk membedakan motif songket Palembang yaitu dengan cara konvensional dengan memerhatikan bentuk, warna, prinsip, dan cara pembuatannya. Semakin berkembangnya zaman sudah banyak penelitian yang dilakukan salah satunya menggunakan bidang ilmu komputer khususnya computer vision dengan beberapa metode untuk mengklasifikasi motif songket Palembang. Terdapat beberapa penelitian yang pernah melakukan pengklasifikasian motif songket Palembang, yaitu dilakukan oleh Andra Riztyan dan Rezi Berli Dariska pada tahun 2013 berhasil melakukan pengenalan motif songket Palembang menggunakan algoritma Propagasi Balik [1], dan juga pernah dilakukan oleh Zikri Khairan pada tahun 2018 perancangan sistem otomatisasi untuk klasifikasi motif songket menggunakan Support Vector Machine [2]. Yohannes dkk melakukan penelitian dalam klasifikasi motif songket Palembang dengan menggunakan ekstraksi fitur Speeded-Up Robust Feature (SURF) dan klasifikasi Random Forest yang menghasilkan rata - rata akurasi sebesar 79,26\% [3].

Dalam melakukan klasifikasi terdapat beberapa fitur untuk mendapatkan informasi dari citra, salah satunya seperti pada penelitian yang pernah dilakukan oleh Dominikus Willy, dkk. pada tahun 2013 berhasil melakukan evaluasi pengenalan Songket menggunakan fitur SIFT dan SURF yang menunjukkan bahwa SIFT memiliki performa yang lebih baik daripada SURF [4] dan Hossam M. Zawbaa, Maryam Hazman, Mona Abbass, Aboul Ella Hassanien pada tahun 2014 berhasil menggunakan fitur SIFT dan Random Forest untuk klasifikasi buah otomatis dan hasilnya secara umum lebih baik daripada KNN dan SVM [5].

Dari penelitian yang telah dilakukan oleh Dominikus, dkk. dan Hossam, dkk., objek yang digunakan memiliki kesamaan yaitu berdasarkan bentuknya. Sehingga dapat memungkinkan untuk dilakukan klasifikasi menggunakan Random Forest dengan fitur SIFT pada objek yang berbeda yaitu motif songket Palembang untuk mengetahui seberapa baik performa yang dihasilkan.

\section{METODE PENELITIAN}

Jalannya proses penelitian ini mengikuti langkah-langkah yang tersaji pada Gambar 1 .

\subsection{Identifikasi Masalah}

Pada tahap ini, peneliti melakukan pengumpulan informasi berupa jurnal terbaru dan teori tentang klasifikasi motif songket Palembang, metode ekstraksi SIFT dan metode klasifikasi 
Random Forest yang digunakan peneliti sebagai referensi dan apa yang harus dilakukan untuk memecahkan masalah.

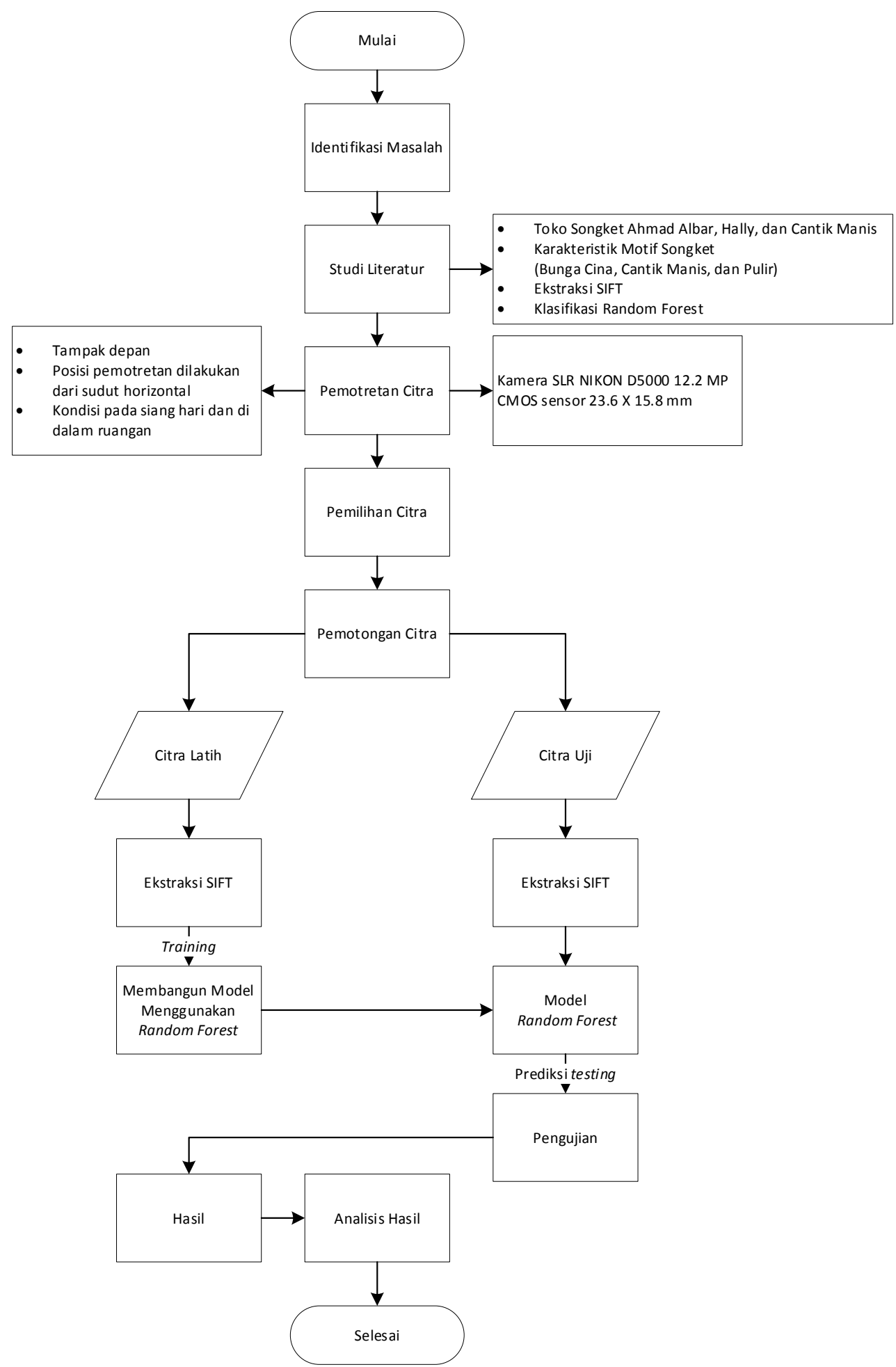

Gambar 1. Diagram Alir Tahapan Penelitian 


\subsection{Studi Literatur}

Tahapan ini merupakan pembelajaran mengenai topik permasalahan penenelitian berdasarkan jurnal yang dikumpulkan, yaitu jurnal yang terkait dengan pengenalan jenis motif songket serta jurnal yang menggunakan metode ekstraksi SIFT, dan metode klasifikasi Random Forest.

\subsection{Pengumpulan Citra}

Pada tahap ini, peneliti melakukan pengumpulan data, data yang digunakan dalam penelitian ini adalah data motif songket Palembang dari 3 motif songket Palembang, dan macam motif yang digunakan meliputi Bunga Cina, Cantik Manis, dan Pulir.

\subsubsection{Pemotretan Citra}

Tahapan ini merupak proses saat melakukan pengambilan gambar objek penelitian. Kamera yang digunakan dalam pemotretan citra adalah kamera DSLR Nikon D5000.

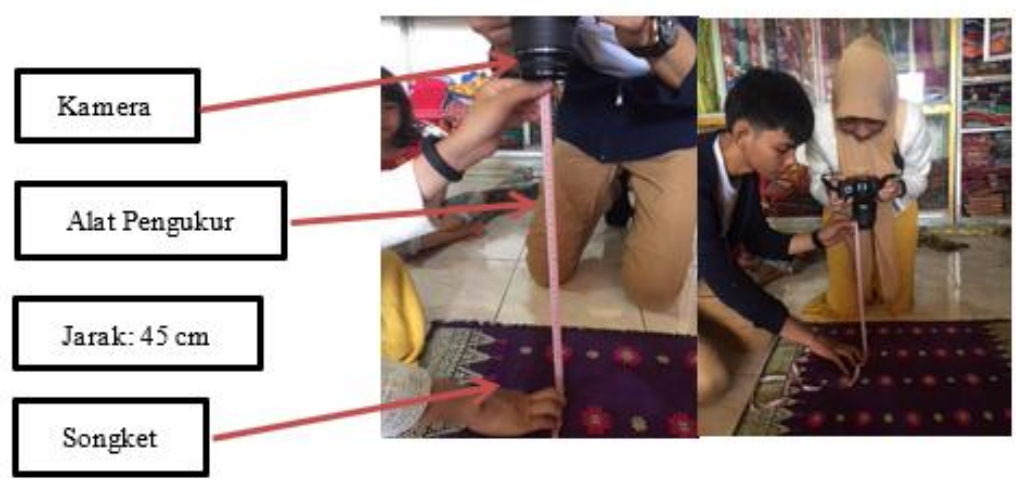

Gambar 2. Proses Pemotretan Citra Motif Songket Palembang

Proses pemotretan citra dilakukan tanpa menggunakan LED flash, jarak pemotretan citra dengan songket Palembang dengan kameranya yaitu sejauh $45 \mathrm{~cm}$, hal ini dilakukan untuk mendapatkan motif citra dengan jumlah banyak dalam sekali potret serta menggunakan meteran sebagai alat bantu pengukuran. Kemudian, untuk proses pengambilan motif songket Palembang dilakukan pada waktu siang hari di dalam ruangan. Kemudian citra yang dipotret diambil dengan posisi kamera secara horizontal.

\subsubsection{Pemotongan Citra}

Tahapan ini, proses pemotongan citra akan dilakukan sesuai dengan jarak yang akan diuji dan telah ditentukan, yaitu pada jarak $45 \mathrm{~cm}$ dengan resolusi kamera 12,2 MP. Adapun ukuran dalam pemotongan citra ini yaitu 256 x 256 piksel. Tujuan dari proses pemotongan citra ini adalah untuk memfokuskan ke titik pusat koordinat yang akan diteliti yaitu pada motif songket Palembang agar dapat terlihat tekstur citranya.

\subsubsection{Pengelompokan Data}

Setelah citra motif songket Palembang didapatkan dan telah melalui proses cropping, maka proses selanjutnya adalah mengelompokkan data citra latih dan citra uji. Citra latih merupakan citra yang akan digunakan pada saat proses pelatihan citra yang untuk menentukan klasifikasi yang cocok. Citra Latih memiliki 3 jenis motif songket Palembang berdasarkan warna yang kain yang berbeda, jumlah keseluruhan data latih 100 per motif songket Palembang. Citra uji merupakan citra yang akan digunakan pada proses pengujian, dan citra uji merupakan 
citra yang akan diklasifikasikan oleh model yang telah dibuat dari 15 citra motif Bunga Cina, 15 citra motif bunga Cantik Manis, dan 15 motif citra Pulir.

\subsection{Ekstraksi SIFT}

Setelah ukuran citra seragam, dilakukan ekstraksi fitur citra menggunakan metode ekstraksi SIFT untuk mendapatkan informasi hasil fitur keypoint. Keypoint yang telah didapat bertujuan untuk mengatasi pengaruh noise. Tahapan ekstraksi fitur SIFT dapat dilihat pada Gambar 3.

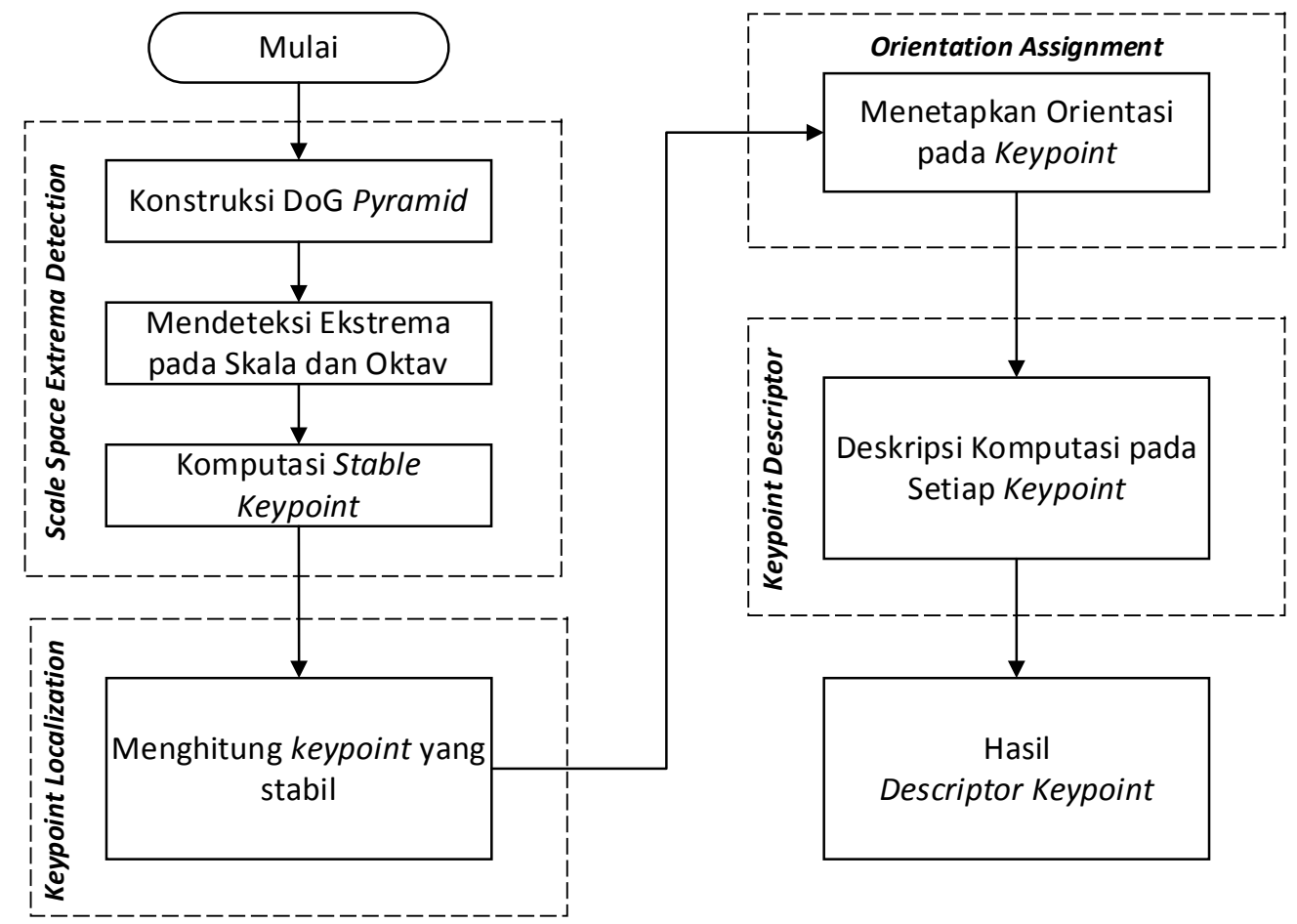

Gambar 3. Tahapan Ekstraksi Fitur SIFT

Tahapan metode SIFT [6] antara lain:

a. Scale Space Extrema Detection

Pada setiap oktaf ruang skala, gambar secara kontinu dihubungkan dengan Gaussian untuk menghasilkan skala gambar ruang yang terlihat pada sebelah kiri. Gambar yang berdekatan dikurangi untuk menghasilkan Difference of Gaussian (DoG) yang ada disebelah kanan. Proses dilakukan secara berulang.

b. Keypoint Localization

Titik tujuan yang ditandai dengan X pada suatu level dibandingkan dengan 26 titik hijau. Jika $\mathrm{X}$ lebih besar atau lebih kecil dari semua titik hijau, akan dianggap sebuah nilai ekstrema lokal (kandidat keypoint).

c. Orientation Assignment

Mendapatkan keypoint maxima dan minima dari DoG. Keypoint dilihat dari vektor sebagai ukuran, orientasi, dan lokasi. Dilanjutkan dengan menerapkan threshold pada minimum contrast, dan setelahnya dilakukan penambahan threshold pada ratio.

d. Keypoint Descriptor

Panah-panah yang diperoleh akan diakumulasi ke dalam histogram orientasi dengan menjumlahkan gradien magnitude yang saling mendekati. 


\subsection{Klasifikasi Random Forest}

Tahap ini merupakan proses mengklasifikasi citra motif songket dengan menggunakan metode klasifikasi Random Forest. Pembentukan model setelah dilakukan ekstraksi fitur SIFT dapat dilihat pada Gambar 4 dan klasifikasi menggunakan Random Forest dapat dilihat pada Gambar 5.

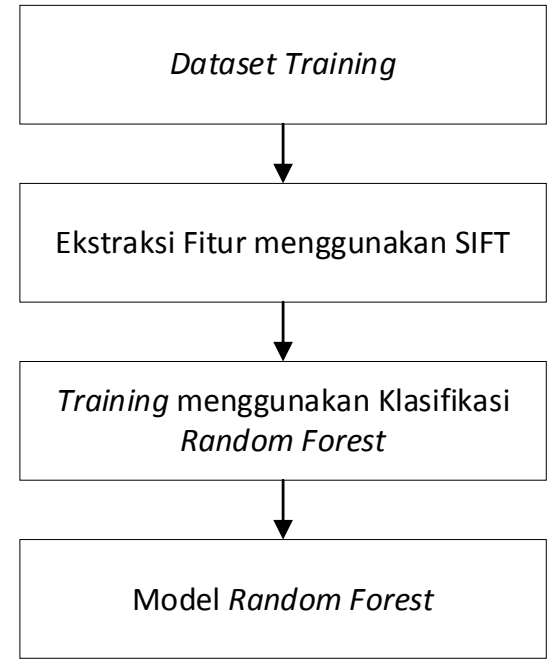

Gambar 4. Pembentukan Model Random Forest

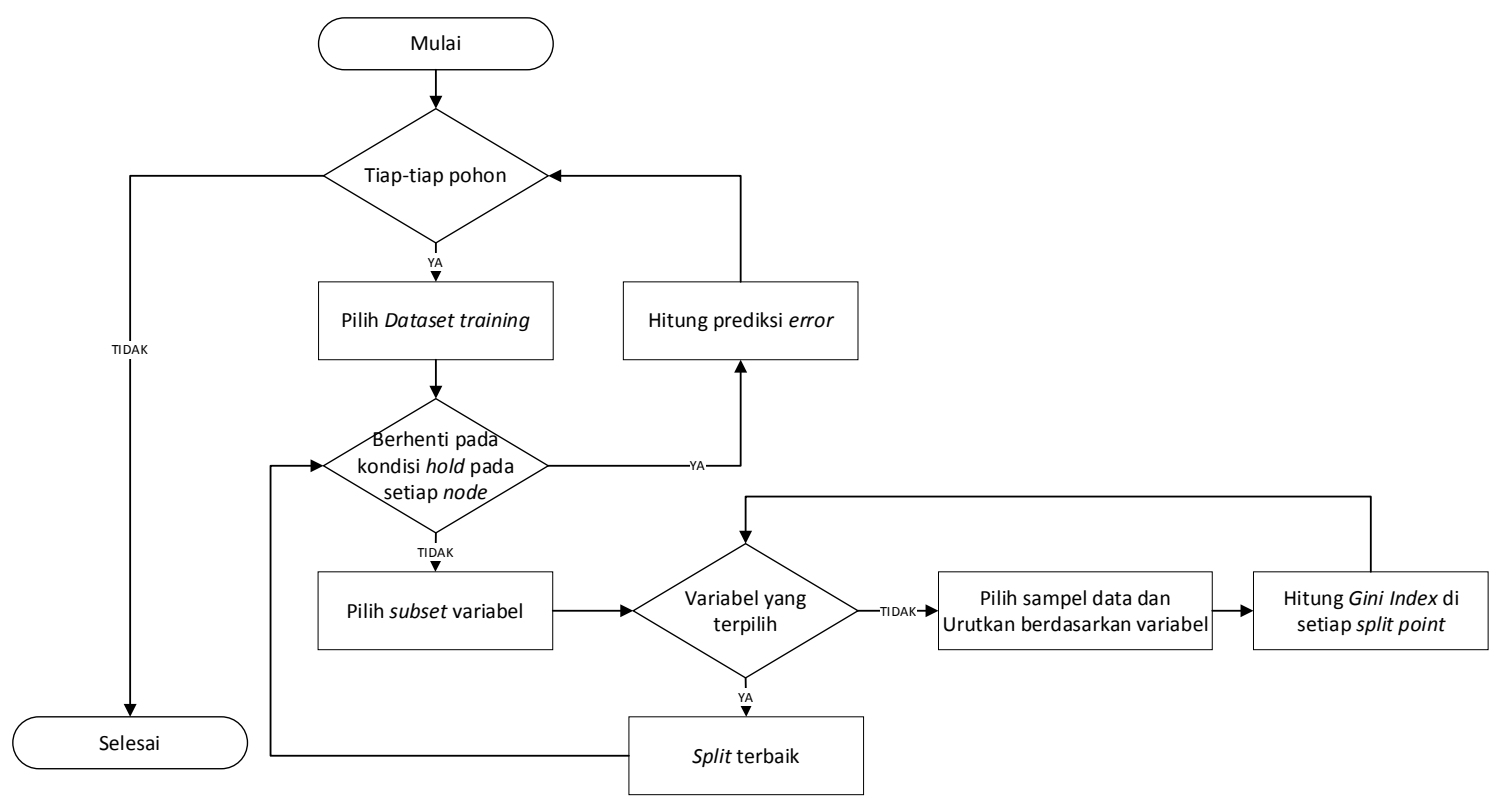

Gambar 5. Flowchart Random Forest

Random forest mempunyai beberapa keunggulan, yaitu dapat meningkatkan akurasi apabila terdapat data yang hilang serta untuk resisting outliers, dan juga efisien untuk penyimpanan data. Tidak hanya itu, pada Random Forest terdapat proses seleksi fitur dimana mampu mengambil fitur terbaik sehingga meningkatkan performa pada model klasifikasi. Dengan adanya fitur seleksi tentunya Random Forest mampu bekerja pada data yang besar dengan parameter yang kompleks secara efektif. Selain itu, Random Forest juga mampu bekerja secara parallel yang dikenal dengan multiple random forest. Namun, Random Forest terkadang 
memiliki nilai yang tidak diharapkan dan juga tidak mempredikasi range dari response nilai pada data latih [7].

\subsection{Evaluasi Hasil Pengujian}

Evaluasi hasil pengujian klasifikasi karakteristik motif songket Palembang dapat diukur menggunakan accuracy, precision, dan recall:

Accuracy $=\frac{T P+T N}{T P+T N+F P+F N} \times 100 \%$.
Precision $=\frac{T P}{T P+F P} \times 100 \%$

Recall $=\frac{T P}{F N+T P} \times 100 \%$

Keterangan:

TP : Jumlah data positif citra yang terklasifikasi dengan benar oleh sistem.

TN : Jumlah data negatif citra yang terklasifikasi dengan benar oleh sistem

FP : Jumlah data positif citra yang terklasifikasi salah oleh sistem

FN : Jumlah data negatif citra yang terklasifikasi salah oleh sistem

\section{HASIL DAN PEMBAHASAN}

Menjelaskan hasil pelatihan, hasil pengujian, dan analisis pengujian dari hasil implementasi ekstraksi fitur menggunakan Sclae-Invariant Feature Transform dan klasifikasi menggunakan Random Forest serta evaluasi hasil pengujian klasifikasi karakteriktik motif Songket Palembang.

\subsection{Hasil Pengujian}

Tahap ini merupakan tahapan dalam mengimplementasikan proses penelitian guna memperoleh hasil penelitian ini, implementasi meliputi tahap ekstraksi SIFT dan tahap klasifikasi Random Forest.

\subsubsection{Implementasi Ekstraksi SIFT}

Pada tahap ini, dilakukan proses ekstraksi SIFT terhadap setiap citra data latih dan data uji. Setiap citra data latih dan data uji yang telah melalui proses ekstraksi akan memperoleh bentuk keypoint descriptor. Berdasarkan hasil keypoint descriptor pada Gambar 6, 7, dan 8, dapat dilihat bahwa objek yang ada pada citra tidak seluruhnya dapat diambil fiturnya oleh metode SIFT, karena warna yang terletak pada background objek hampir sama dengan warna yang dimiliki oleh objek itu sendiri. Hal ini mengakibatkan metode SIFT tidak mampu mengambil fitur pada objek secara sempurna. 


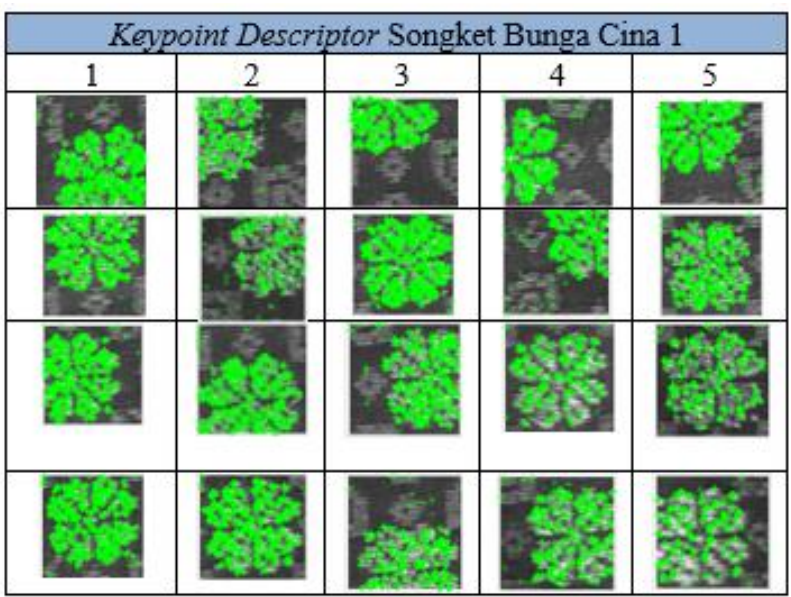

Gambar 6. Keypoint Descriptor Motif Songket Bunga Cina

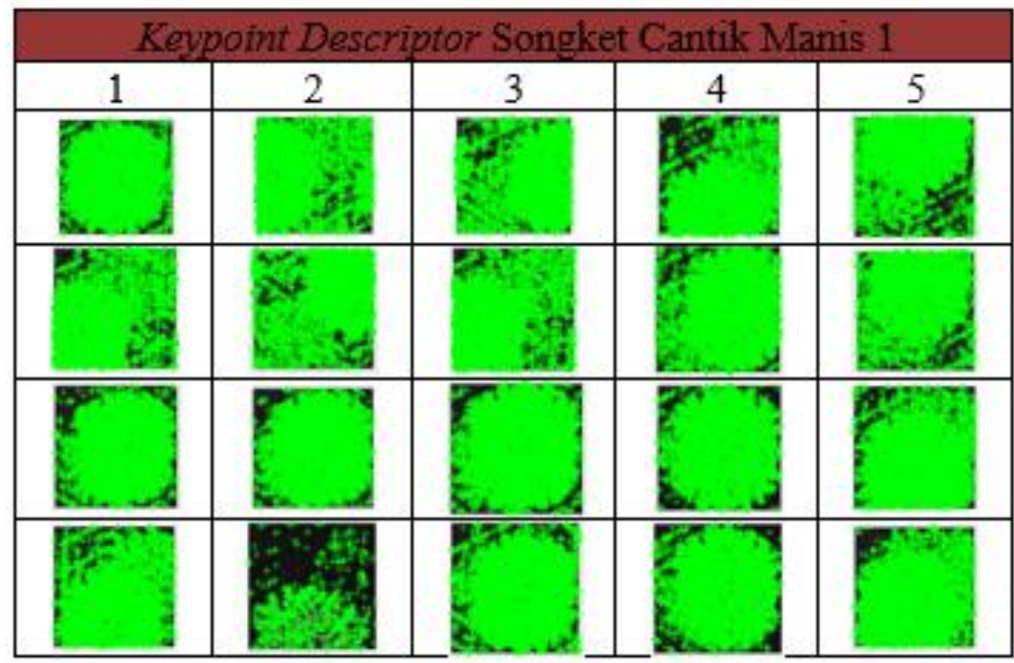

Gambar 7. Keypoint Descriptor Motif Songket Cantik Manis

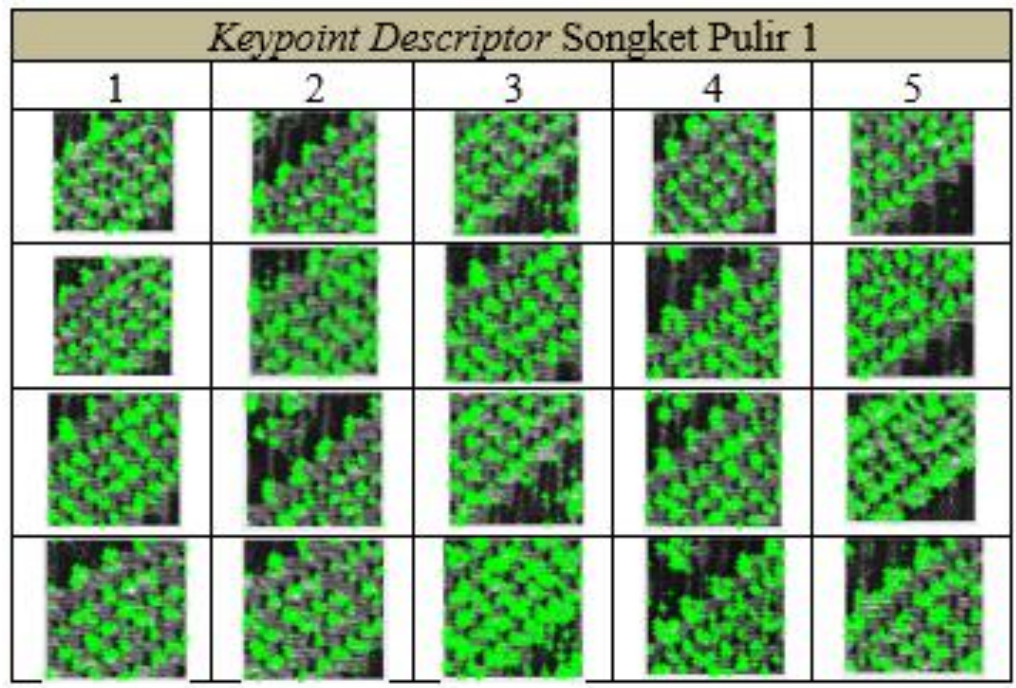

Gambar 8. Keypoint Descriptor Motif Songket Pulir 


\subsubsection{Implementasi Klasifikasi Random Forest}

Tahap ini merupakan tahapan dalam menerapkan metode klasifikasi Random Forest untuk mendapatkan classifier yang berbentuk pohon kemudian pada masing-masing pohon memilih class yang paling popular. Klasifikasi Random Forest mampu mengenali bentuk karakteristik dari motif songket Bunga Cina lebih mudah dibandingkan dengan motif Cantik Manis, dan Pulir. Hal ini dikarenakan urutan nodes yang dihasilkan oleh random forest untuk motif Bunga Cina terletak pada nodes level kedua, kemudian disusul oleh motif songket Cantik Manis, dan Pulir.

\subsection{Confusion Matrix}

Tahapan ini merupakan tahapan confusion matrix untuk mendapatkan hasil prediksi kelas melalui klasifikasi Random Forest berdasarkan classifier yang sesuai antara nilai keypoint descriptor data latih dan nilai keypoint descriptor data uji. Sehingga dapat diketahui hasil confusion matrix-nya pada Gambar 9.

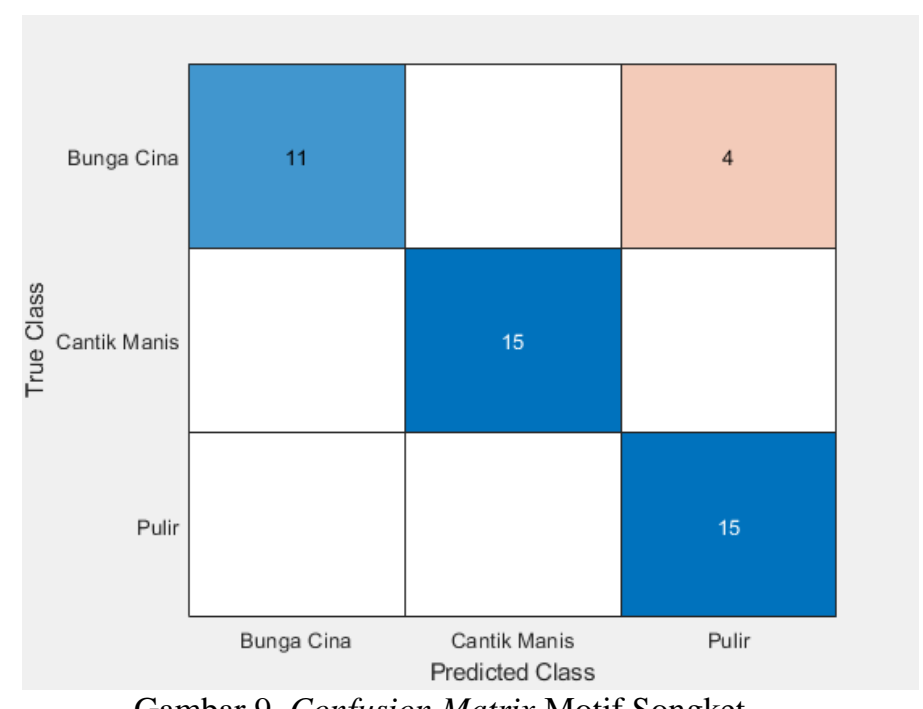

Gambar 9. Confusion Matrix Motif Songket

\subsection{Hasil Klasifikasi}

Dari Tabel 1, dapat diketahui bahwa hasil tingkat pengenalan terbanyak yang diperoleh dalam pengujian menggunakan model Random Forest. Evaluasi hasil pengujian klasifikasi karakteristik motif songket Palembang dapat dilihat pada Tabel 1.

Tabel 1. Accuracy, Precision, dan Recall Klasifikasi Motif Songket

\begin{tabular}{|c|c|c|c|c|c|c|c|}
\hline Motif & TP & TN & FP & FN & $\begin{array}{c}\text { Accuracy } \\
(\mathbf{\%})\end{array}$ & $\begin{array}{c}\text { Precision } \\
(\mathbf{\%})\end{array}$ & $\begin{array}{c}\text { Recall } \\
(\mathbf{\%})\end{array}$ \\
\hline Bunga Cina & 11 & 30 & 0 & 4 & 91,11 & 100 & 69,23 \\
\hline $\begin{array}{c}\text { Cantik } \\
\text { Manis }\end{array}$ & 15 & 30 & 0 & 0 & 100 & 100 & 100 \\
\hline Pulir & 15 & 26 & 4 & 0 & 91,11 & 78,94 & 100 \\
\hline & 41 & 86 & 4 & 4 & 94,07 & 92,98 & 89,74 \\
\hline
\end{tabular}

Berdasarkan Tabel 1, untuk hasil evaluasi yang dimiliki oleh motif songket Bunga Cina, yaitu dengan nilai class accuracy sebesar $91,11 \%$, precision $100 \%$, dan recall sebesar $69,23 \%$. Selanjutnya motif songket Cantik Manis dengan accuracy sebesar 100\%, precision 100\%, dan 
recall sebesar $100 \%$, dan terakhir motif songket Pulir dengan nilai accuracy sebesar $91,11 \%$, precision sebesar $78,94 \%$, dan recall sebesar $100 \%$.

\section{KESIMPULAN}

Berdasarkan hasil penelitian implementasi Random Forest untuk klasifikasi motif songket Palembang berdasarkan Scale-Invariant Feature Transform, dapat disimpulkan sebagai berikut:

1. Objek citra tidak seluruhnya dapat diklasifikasi oleh metode Random Forest karena motif yang tersimpan pada dataset training tidak memiliki kesamaan dengan motif yang ada pada data testing.

2. Nilai per class accuracy terbaik pada motif songket Cantik Manis sebesar $100 \%$, pada motif songket Bunga Cina, dan Pulir sebesar 91,11\%.

3. Nilai precision motif songket Bunga Cina, dan Cantik Manis sebesar $100 \%$, pada motif songket Pulir sebesar 78,94\%.

4. Nilai recall songket Cantik Manis, dan Pulir sebesar $100 \%$, kemudian pada motif songket Bunga Cina sebesar 69,23\%.

\section{SARAN}

Dari penelitian yang telah dilakukan, saran yang direkomendasikan untuk penelitian selanjutnya sebagai berikut:

1. Menambah lebih banyak jumlah citra motif songket Palembang untuk hasil yang lebih baik.

2. Menggunakan metode ekstraksi fitur selain SIFT dan metode selain Random Forest untuk klasifikasi citra motif songket Palembang.

\section{DAFTAR PUSTAKA}

[1] C. S. K. Aditya, M. Hani'ah, R. R. Bintana, and N. Suciati, "Batik Classification Using Neural Network With Gray Level Co-Occurence Matrix and Statistical Color Feature Extraction," Int. Conf. Information, Commun. Technol. Syst., pp. 163-168, 2015.

[2] K. Zikri, "Perancangan Sistem Otomatisasi Untuk Klasifikasi Motif Songket Menggunakan Metode Support Vector Machine," Universitas Andalas, 2015.

[3] Y. Yohannes, S. Devella, and A. H. Pandrean, "Penerapan Speeded-Up Robust Feature pada Random Forest untuk Klasifikasi Motif Songket Palembang," JuTISI, Vol. 5, No. 3, 2019.

[4] D. Willy, A. Noviyanto, and A. M. Arymurthy, "Evaluation of SIFT and SURF Features In The Songket Recognition," 2013 Int. Conf. Adv. Comput. Sci. Inf. Syst. ICACSIS 2013, pp. 393-396, 2013.

[5] H. M. Zawbaa, M. Hazman, M. Abbass, and A. E. Hassanien, "Automatic Fruit Classification Using Random Forest Algorithm," 2014 14th Int. Conf. Hybrid Intell. Syst. HIS 2014, pp. 164-168, 2014.

[6] D. G. Low, "Distinctive Image Features From Scale-Invariant Keypoints," Int. J. Comput. Vis., pp. 91-110, 2004. 
Jatisi

ISSN 2407-4322

Vol. 7, No. 2, Agustus 2020, Hal. 310-320 E- ISSN 2503- 2933

[7] P. Kashyap, Machine Learning for Decision Makers. Apress, Berkeley, CA, 2017. 